\title{
Effects of miR-27a upregulation on thyroid cancer cells migration, invasion, and angiogenesis
}

\author{
Y.L. Wang1, W.G. Gong ${ }^{2}$ and Q.L. Yuan ${ }^{3}$ \\ ${ }^{1}$ Clinical Laboratory, Linyi Coal Shandong Hot Spring Spa, Shandong, China \\ ${ }^{2}$ Clinical Laboratory, People's Hospital of Mengyin County, Shandong, China \\ ${ }^{3}$ Clinical Laboratory, People's Hospital of Linshu County, Shandong, China \\ Corresponding author: Y.L. Wang \\ E-mail: pingzhouiop@sina.com
}

Genet. Mol. Res. 15 (4): gmr15049070

Received August 11, 2016

Accepted November 17, 2016

Published December 19, 2016

DOI http://dx.doi.org/10.4238/gmr15049070

Copyright $(2016$ The Authors. This is an open-access article distributed under the terms of the Creative Commons Attribution ShareAlike (CC BY-SA) 4.0 License.

\begin{abstract}
Thyroid cancer is the most common type of endocrine tumor. MicroRNAs (miRNAs) play a critical role in a variety of diseases, especially cancer occurrence and progression. However, the specific mechanism by which miRNAs trigger disease states has not been fully elucidated. This study aims to investigate the role of miR-27a in thyroid cancer cells. A wound healing assay was adopted to examine cell migration. A transwell assay was applied to assess cell invasion. A thyroid cancer xenograft model was established using BALB/c nude mice. Western blot was performed to quantify iNOS expression. Tumor tissue blood vessel density was evaluated via immunohistochemistry assays. The results indicated that miR-27a downregulation inhibited thyroid cancer cell migration, while upregulation of miR-27a promoted thyroid cancer cell migration $(\mathrm{P}<0.05)$. Furthermore, reduction in miR27 a expression suppressed thyroid cancer cell invasion $(\mathrm{P}<0.05)$. In the
\end{abstract}


nude mouse model of thyroid cancer xenograft, upregulation of miR-27 induced iNOS expression in pathological tumor tissues, whereas miR27 a inhibition resulted in the opposite effect $(\mathrm{P}<0.05)$. CD105 level was also significantly increased during miR-27a upregulation, and was declined when miR-27a was inhibited $(\mathrm{P}<0.05)$. In conclusion, miR27 a upregulation in thyroid cancer cells affects tumor cell migration, invasion, and angiogenesis by targeting downstream genes. Therefore, miR27a may act as a biomarker of thyroid cancer.

Key words: Thyroid cancer; miRNA; Cell migration; Cell invasion; Angiogenesis

\section{INTRODUCTION}

Thyroid cancer is the most common type of endocrine tumor, and its incidence has increased over the years (Gao et al., 2016). Thyroid papillary carcinoma is the most common pathological type of thyroid cancer. Although it is known for its low malignancy rate and has good disease prognosis, local recurrence is closely associated with tumor progression. Currently, there is still a lack of specific prevention and control strategies for this disease. Therefore, early diagnosis and therapeutic targets for thyroid papillary carcinoma are essential to prolong patient survival.

In the recent years, it has been shown that microRNAs (miRNAs) play a critical role in a variety of diseases, especially in cancers (Wang et al., 2012; Cao et al., 2014; Qi et al., 2015). A miRNA is a type of non-coding single-stranded RNA, usually between 18 to $24 \mathrm{bp}$ long. It can completely or partially bind to the 3 'UTR of target mRNA via complementary binding. Under the effect of RNA exonuclease, miRNAs can selectively degrade mRNA to inhibit or activate downstream genes (Bai et al., 2009). miRNAs mainly regulate downstream genes by suppressing mRNA transcription. Therefore, mRNAs can also regulate cell function and oncogene activation through downregulation of functional proteins (Lu et al., 2005). Recently, numerous studies have examined the role of miR-27a in cancer progression. miR-27a was reported to promote drug-induced immune cells death in colon cancer (Colangelo et al., 2016), and to affect the activity of thymus gland cancer cells (Zhou et al., 2016). Moreover, specific miRNAs were shown to improve diagnostic sensitivity and specificity of hepatocellular carcinoma (Zuo et al., 2016). In addition, miRNAs were revealed to regulate ZBTB10 (Tang et al., 2014) and PATZ1 (Sun et al., 2010), which play critical roles in thyroid cancer. However, the exact role of miR-27a in thyroid cancer has not been investigated.

In this study, we adopted both in vitro and in vivo models to examine the effect of miR-27a in thyroid cancer. Specifically, we aimed to investigate the role of miR-27a in thyroid cancer cell migration and invasion at the cellular level, and to explore its effects on angiogenesis in the tumor xenograft nude mouse model.

\section{MATERIAL AND METHODS}

\section{Main reagents}

Total protein extraction kit was purchased from Qiagen (Qiagen Inc. Co., Hilden, Germany). Western blot lysis, BCA protein quantification kit, and immunoprecipitation

Genetics and Molecular Research 15 (4): gmr15049070 
protein $\mathrm{A}+\mathrm{G}$ agarose were provided by Beyotime Inc. Co. (Shanghai, China). Rabbit antimouse iNOS monoclonal antibody and rabbit anti-mouse CD105 polyclonal antibody were obtained from Proteintech Inc. Co. (Rosemont, IL, USA). HRP labeled goat anti-mouse IgG $(\mathrm{H}+\mathrm{L})$ (and HRP labeled goat anti-rabbit IgG $(\mathrm{H}+\mathrm{L})$ were bought from ZSGB Bio. Inc. Co. (Beijing, China).

\section{Cell culture}

The thyroid papillary cancer cell line, IHH-4, was purchased from the cell bank of the Chinese Academy of Sciences (Shanghai, China). The cells were maintained in DMEM (Dulbecco's Modified Eagle's medium) supplemented with 10\% FBS, $100 \mathrm{U} / \mathrm{mL}$ penicillin, and $100 \mathrm{mg} / \mathrm{mL}$ streptomycin. Cells were cultured at $37^{\circ} \mathrm{C}$ with $5 \% \mathrm{CO}_{2}$.

\section{Wound healing assay}

Cells were cultured in 6-well plates, and were scraped with a $200-\mu \mathrm{L}$ tip when $90 \%$ confluence was reached. After washing 3 times with PBS, cells were imaged under the microscope. Following a 12-h incubation period, cells were imaged again to calculate migration. All in vitro assays were replicated at least 6 times.

\section{Transwell assay}

Transwell chambers were pre-cooled at $4^{\circ} \mathrm{C}$, and the extracellular matrix (ECM)based matrigel was thawed at $4^{\circ} \mathrm{C}$. Transwell chambers were then inserted into the wells of a 24-well plate, and were coated with $50 \mu \mathrm{L}$ diluted ECM matrigel at $37^{\circ} \mathrm{C}$ for $4 \mathrm{~h}$. The cells were digested by enzyme and were seeded into the upper chamber; DMEM supplemented with $10 \%$ FBS was added to the lower chamber. Following incubation, the membrane was stained with $0.1 \%$ crystal violet, and was observed under the microscope for cell counting.

\section{miR-27a mimic and miR-27 inhibitor}

The miR-27a mimic sequence (5'-UACGG UUUCA ACAGU GUGGA-3') and miR27a inhibitor sequence (5'-ACUUG UGCGG UCUAG AGA-3') were sub-cloned into the pcDNA3.1 vector (Invitrogen, Carlsbad, CA, USA) to obtain the pcDNA3.1-miR-27a plasmid and the pcDNA3.1-miR-27 inhibitor plasmid. The miR-27a mimic and the miR-27a inhibitor were synthesized by Gene Pharma (Shanghai, China). The plasmids were transfected using the lipofectamine 2000 reagent (Invitrogen). The transfection complexes were prepared according to manufacturer instructions.

\section{Grouping of experimental animals}

Male and female BALB/c nude mice were provided by Vitalriver (Beijing, China), and were raised under the specific pathogen free barrier system. The mice ranged between 4-8 weeks of age, and weighed between 16-18 g. Mice were randomly divided into control, miR-27a upregulation, and miR-27a downregulation groups, with 10 animals in each group. Control mice received no treatment after tumor inoculation, whereas the treatment groups

Genetics and Molecular Research 15 (4): gmr15049070 
received either the miR-27a upregulator or the inhibitor via tail vein injection at $50 \mathrm{ng} / \mathrm{kg} / \mathrm{day}$ for 28 days. The study protocol was approved by the Institutional Care and Use of Animals Committee of The Third Xiangya Hospital of Central South University, Changsha, China.

\section{Thyroid cancer xenograft model establishment}

The thyroid cancer xenograft model was established according to protocols described by Yin et al. (2016). IHH-4 cells at 90\% fusion rate were digested by enzymes and resuspended in PBS at $1 \times 10^{7}$ cells $/ 200 \mu \mathrm{L}$. A total of $0.2 \mathrm{~mL}$ cell suspension was $s c$ injected into the neck of nude mice. General behavior, including activity and eating, were monitored daily. Animals were sacrificed on the 30th day, and tumor tissues were extracted.

\section{Western blot}

Phenylmethylsulfonyl fluoride was added to the lysis buffer at $1 \mathrm{mM}$ final concentration. A total of $100 \mathrm{mg}$ tumor tissue was digested in lysis buffer at $4^{\circ} \mathrm{C}$ for $15 \mathrm{~min}$. Following centrifugation at $10,000 \mathrm{~g}$ for $15 \mathrm{~min}$, protein content in the supernatant was quantified by the BCA method. Next, protein was denatured in boiling water for $5 \mathrm{~min}$, and was stored at $-20^{\circ} \mathrm{C}$. Proteins were separated by $8-12 \%$ SDS-PAGE, and were transferred to a PVDF membrane at $300 \mathrm{~mA}$ for $1 \mathrm{~h}$. The membrane was incubated with iNOs primary antibody $(1: 1000)$ at $4^{\circ} \mathrm{C}$ overnight, and was further incubated in goat anti-rabbit secondary antibody $(1: 1000)$ at $37^{\circ} \mathrm{C}$ for $2 \mathrm{~h}$. Proteins of interest were detected by chemiluminiscence, and was visualized using a Chemi HR camera on the Bio-rad system. Lastly, protein expression was analyzed by the GelPro Analyzer Version 4.0 software.

\section{Immunohistochemistry}

Tumor tissue was fixed in $10 \%$ formaldehyde for $24 \mathrm{~h}$, and was then embedded in paraffin. Tissue sections were dewaxed, and incubated in 3\% hydrogen peroxide for 20 min to eliminate endogenous peroxidase the activity. Epitope retrieval was performed in citrate buffer at $95^{\circ} \mathrm{C}$ for $10 \mathrm{~min}$, after which the sections were blocked in goat serum for $20 \mathrm{~min}$. Tissues were incubated in CD105 primary antibody $(1: 100)$ at $4^{\circ} \mathrm{C}$ overnight, washed with PBS, and further incubated with HRP labeled secondary antibody. Sections were then washed and developed by $3,3^{\prime}$ diaminobenzidine.

\section{Statistical analysis}

All data analysis was performed with the SPSS 19.0 software. Data are reported as means \pm SD. Normally distributed data sets were compared using the Student $t$-test. $\mathrm{P}<0.05$ was considered to be statistically significant.

\section{RESULTS}

\section{MiR-27a upregulation promoted thyroid cancer cell migration}

Wound healing assay results demonstrated that cell migration was enhanced 
significantly $24 \mathrm{~h}$ following miR-27a upregulation by miR-27a mimics ( $74.5 \pm 6.1 \%)$, compared to that observed in the control group $(40.9 \pm 3.6 \%)$ (Figure $1, \mathrm{P}<0.05)$. Conversely, cell migration decreased after miR-27a inhibitor treatment (31.6 $\pm 5.3 \%)$, though not significantly, suggesting that miR-27a upregulation may enhance cell migration (Figure 1).

A

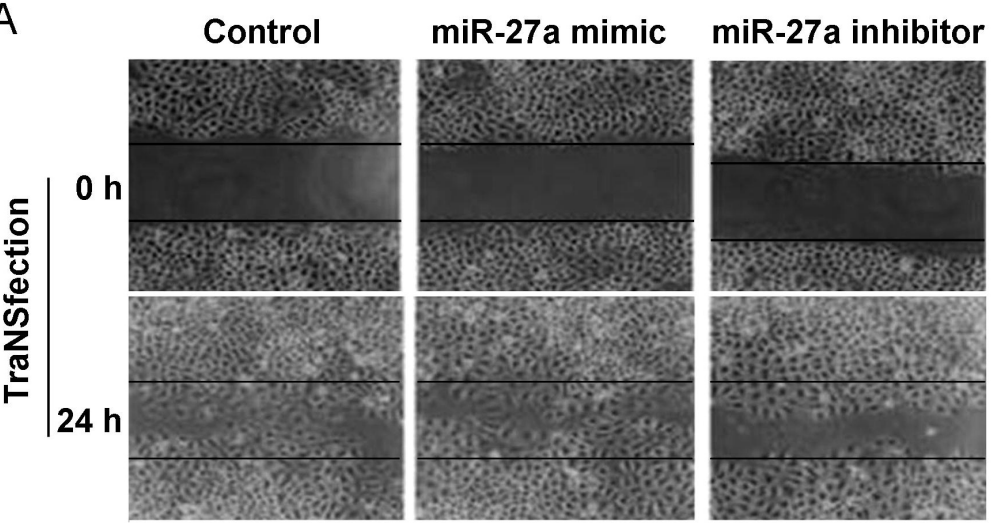

$\mathrm{B}$

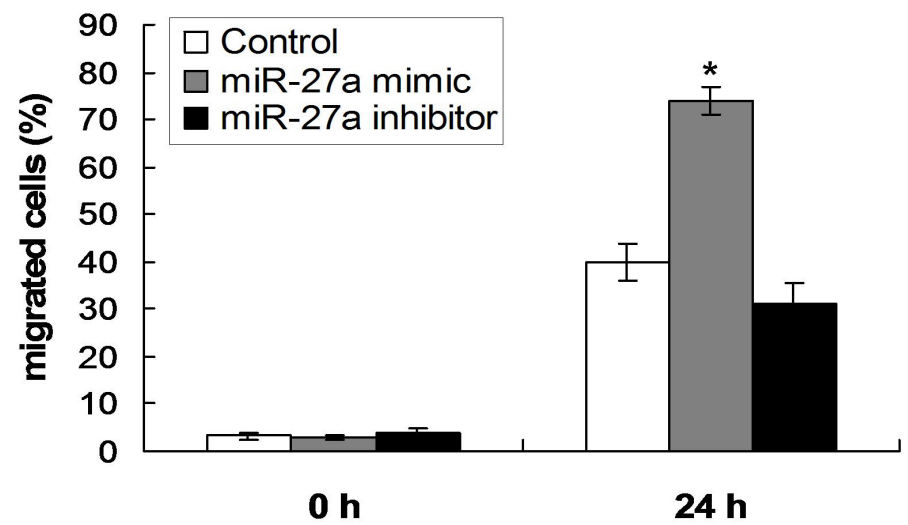

Figure 1. Cell migration after miR-27a mimic or inhibitor treatment. A. Cell migration assay. B. Statistical analysis for cell migration. $* \mathrm{P}<0.05$, compared with normal control $(\mathrm{N}=6)$.

\section{MiR-27a upregulation enhanced invasion of thyroid cancer cells}

Invasion of thyroid cancer cells was evaluated via the transwell assay following treatments with either the miR-27 mimic or the inhibitor. We found that $24 \mathrm{~h}$ following miR-27a upregulation, the number of cells passing through the membrane was significantly increased $(37.6 \pm 5.3)$ compared to that in the control group $(19.1 \pm 4.5)(\mathrm{P}<0.05)$. In addition, miR27 a inhibitor reduced cell invasion $(14.9 \pm 0.6)$, compared with that in the control (Figure 2). These results suggested that miR-27a upregulation enhances invasion of thyroid cancer cells.

Genetics and Molecular Research 15 (4): gmr15049070 


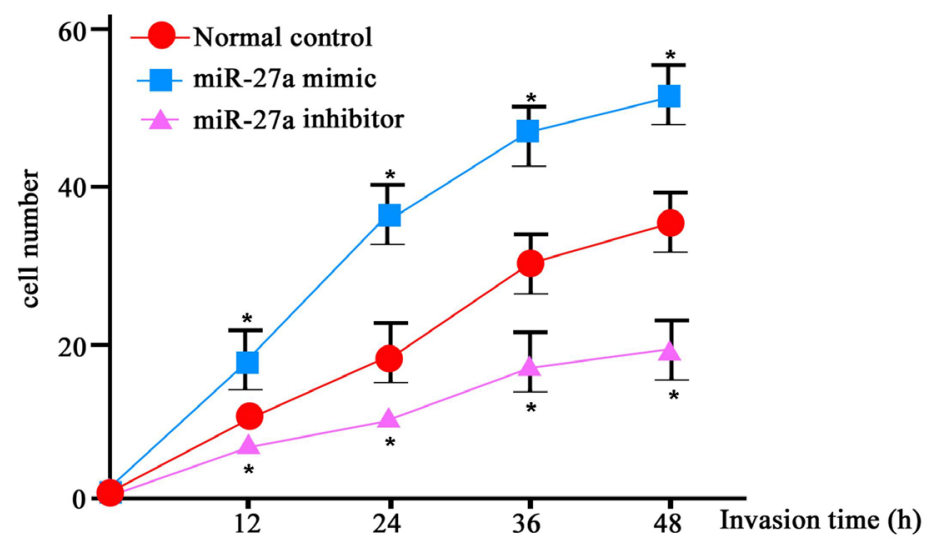

Figure 2. Effect of miR-27a on cell invasion. Data were analyzed using the Student $t$-test. $* \mathrm{P}<0.05$, compared with normal control $(\mathrm{N}=6)$.

\section{Effect of miR-27a upregulation on iNOs expression}

iNOs is an early marker of angiogenesis (Cheng et al., 2014a; El-Sehemy et al., 2016). We examined iNOs expression in tumor tissues from nude mouse xenografts. As shown in Figure 3, iNOs expression was significantly elevated in the miR-27a mimic group $(1.68 \pm 0.32)$ compared with that in the control group $(1.00 \pm 0.21)(\mathrm{P}<0.05)$. As expected, its expression was downregulated in the miR-27a inhibitor group $(1.11 \pm 0.18)$ (Figure 3$)$. Therefore, miR27 a upregulation may promote angiogenesis in thyroid cancer tissues.
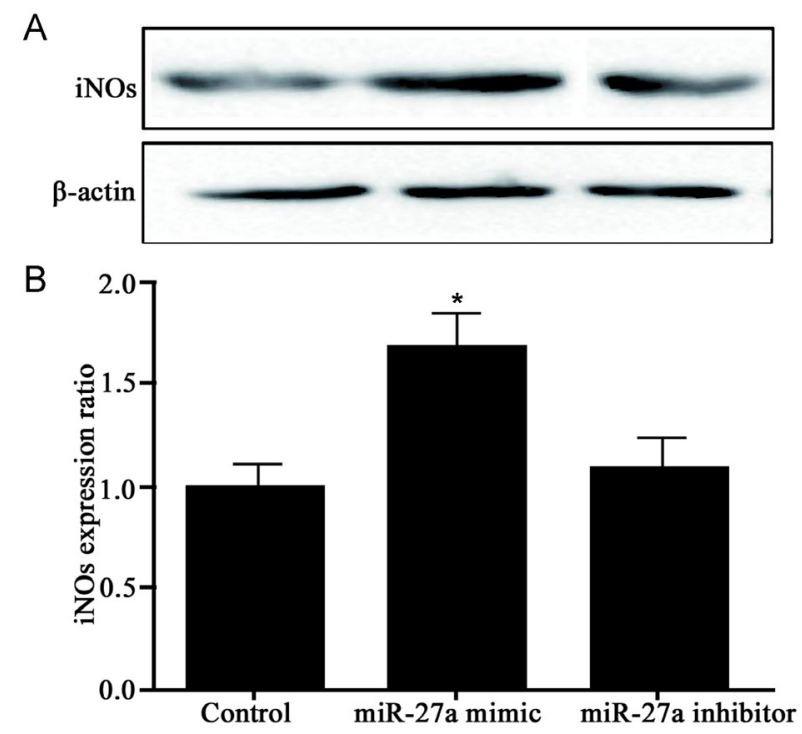

Figure 3. Effect of miR-27a on iNOs expression in thyroid cancer xenografts. A. Western blot assay for iNOS expression. B. Densitometry of iNOS expression detected by western blot. Data were analyzed by the Student $t$-test. $* \mathrm{P}<0.05$, compared with normal control $(\mathrm{N}=10)$. 


\section{Effect of miR-27a on blood vessel density in thyroid cancer tissues}

Immunohistochemistry was used to detect density of neovascularization, as described previously (Cheng et al., 2014b). As shown in Figure 4, CD105 level was significantly increased in miR-27a mimic treated mice $(71.2 \pm 7.8 \%)$ compared to that in the control group $(55.1 \pm 5.5 \%)(\mathrm{P}<0.05)$. The opposite trend was observed when animals were treated with the miR-27a inhibitor $(10.5 \pm 2.6 \%)$ (Figure 4$)$, suggesting that miR-27a upregulation promotes angiogenesis.

A

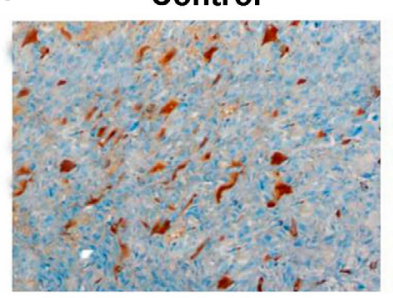

miR-27a mimic

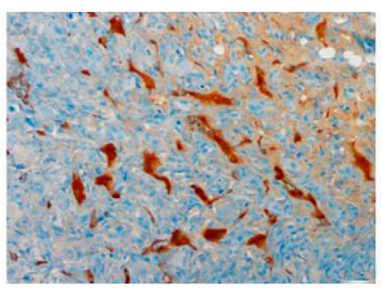

miR-27a inhibitor

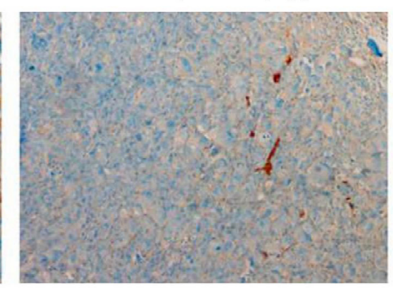

$\mathrm{B}$

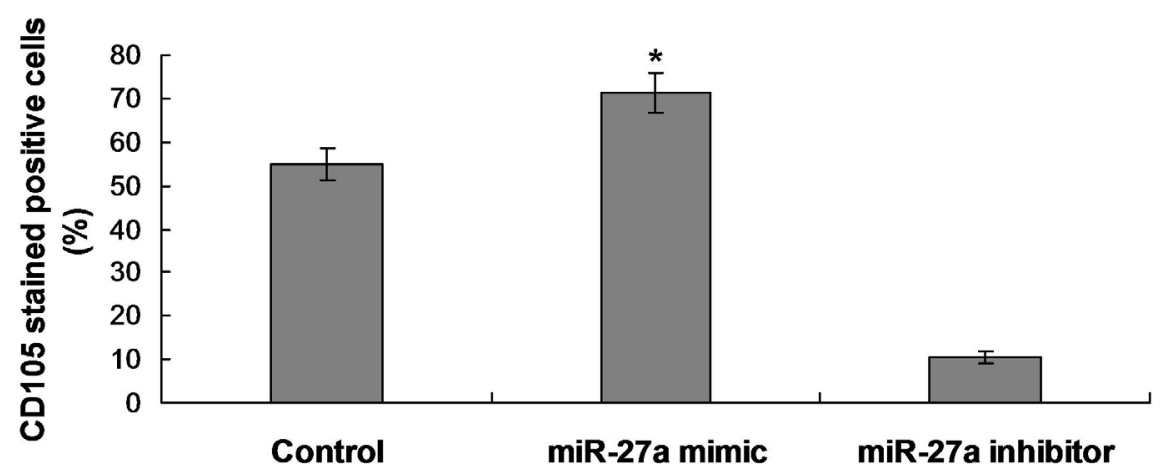

Figure 4. Effect of miR-27a on angiogenesis. A. Immunohistochemistry assay for CD105 expression. B. Statistical analysis for the CD105 expression. $* \mathrm{P}<0.05$, compared with normal control $(\mathrm{N}=10)$.

\section{DISCUSSION}

Papillary thyroid carcinoma, one of the most common types of differentiated thyroid cancers, belongs to a class of thyroid microcarcinomas with primary lesion diameters less than $1.0 \mathrm{~cm}$. It is also regarded as the thyroid cancer that shows the greatest rise in incidence (Beksac et al., 2016). It commonly appears in females aged 20-40 years, and does not present with obvious symptoms. Capsule hemorrhage can lead to sudden thyroid enlargement, resulting in nodular tumors with smooth edges that can move up and down during swallowing (Matsuno et al., 2013). Although the degree of malignancy for papillary thyroid carcinomas is low, and patients have good disease prognosis, its local recurrence may be associated with tumor progression. Currently, there is still a lack of clear prevention and control measures for this disease. Therefore, early diagnosis and treatment is of great significance to prolong patient 
survival. The discovery of potential therapeutic target in the basic research is particularly important (Hong et al., 2016). In recent years, it has been shown that miRNAs play important roles in a variety of diseases. miRNAs are a type of non-coding small single-stranded RNAs, usually between 18-24 bp long, that can completely or partially bind to the complementary 3'UTR of target mRNAs. RNA exonuclease can selectively degrade mRNAs, thus regulating downstream gene inhibition or activation (Huang et al., 2016). miRNAs mainly regulate downstream genes by inhibiting transcription. They can also affect cell function and oncogene activation through downregulation of several proteins (Frediani and Fabbri, 2016) (Frediani \& Fabbri, 2016). The regulatory role of miRNAs in protein synthesis under physiological conditions is extremely important. miRNA dysregulation is associated with a variety of human cancers, including thymic carcinoma (Joyce et al., 2016), liver cancer (Otsuka et al., 2016), and bile duct carcinoma (Pisarello et al., 2015; Mutalib et al., 2016). Different miRNAs play critical roles in different kinds of malignant tumors.

MiR-27a is a popular miRNA in research, and has been confirmed to be associated with cancer malignancy. It was also evaluated as a potential biomarker to improve diagnostic sensitivity and specificity (Zuo et al., 2016). This study investigated the effect of miR-27a on thyroid cancer cell migration, invasion, and angiogenesis in both cell lines and animal models. At the cellular level, miR-27a upregulation promoted migration and invasion of cancer cells. However, tumor metastasis is a complicated process, where tumor cells need to also pass through the cellular matrix and the vascular wall in order to enter into the circulatory system (Thakur and Bedogni, 2016). Therefore, we used the transwell assay to investigate the effect of miR-27a on tumor invasion during simulated tumor metastasis. In animal models, nude mice were subcutaneously inoculated with thyroid tumor cells evaluate the effect of miR-27a. It was determined that miR-27a upregulation may promote angiogenesis in tumor tissues.

Regulation of miRNAs in thyroid tumors is an extremely complicated process with numerous factors (Valderrabano et al., 2015). We confirmed that miR-27a promotes thyroid cancer migration, invasion, and angiogenesis under both in vitro and in vivo settings. However, the specific mechanisms by which it acts is still unclear, and is in need of further in-depth research. It is possible that miR-27a inhibitors could be used as a target in the treatment of thyroid carcinoma.

\section{CONCLUSION}

The level of miR-27a can have an effect on thyroid cancer cell migration and invasion; miR-27a upregulation was found to be associated with migration, invasion, and angiogenesis of thyroid cancer cells. Therefore, miR-27a could be used as a marker to monitor progression of thyroid cancers.

\section{Conflicts of interest}

The authors declare no conflict of interest.

\section{ACKNOWLEDGMENTS}

We thank the anonymous reviewers for reviewing this manuscript.

Genetics and Molecular Research 15 (4): gmr15049070 
miR-27a in thyroid cancer

\section{REFERENCES}

Bai S, Nasser MW, Wang B, Hsu SH, et al. (2009). MicroRNA-122 inhibits tumorigenic properties of hepatocellular carcinoma cells and sensitizes these cells to sorafenib. J. Biol. Chem. 284: 32015-32027. http://dx.doi.org/10.1074/ jbc.M109.016774

Beksac K, Sonmez C, Cetin B, Kismali G, et al. (2016). Evaluation of proinflammatory cytokine and neopterin levels in women with papillary thyroid carcinoma. Int. J. Biol. Markers 0 http://dx.doi.org/10.5301/jbm.5000214.

Cao Y, Hu J, Fang Y, Chen Q, et al. (2014). Association between a functional variant in microRNA-27a and susceptibility to colorectal cancer in a Chinese Han population. Genet. Mol. Res. 13: 7420-7427. http://dx.doi.org/10.4238/2014. September. 12.8

Cheng H, Wang L, Mollica M, Re AT, et al. (2014a). Nitric oxide in cancer metastasis. Cancer Lett. 353: 1-7. http://dx.doi. org/10.1016/j.canlet.2014.07.014

Cheng SH, Liu JM, Liu QY, Luo DY, et al. (2014b). Prognostic role of microvessel density in patients with renal cell carcinoma: a meta-analysis. Int. J. Clin. Exp. Pathol. 7: 5855-5863.

Colangelo T, Polcaro G, Ziccardi P, Muccillo L, et al. (2016). The miR-27a-calreticulin axis affects drug-induced immunogenic cell death in human colorectal cancer cells. Cell Death Dis. 7: e2108. http://dx.doi.org/10.1038/ cddis.2016.29

El-Sehemy A, Postovit LM and Fu Y (2016). Nitric oxide signaling in human ovarian cancer: A potential therapeutic target. Nitric Oxide 54: 30-37. http://dx.doi.org/10.1016/j.niox.2016.02.002

Frediani JN and Fabbri M (2016). Essential role of miRNAs in orchestrating the biology of the tumor microenvironment. Mol. Cancer 15: 42. http://dx.doi.org/10.1186/s12943-016-0525-3

Gao X, Wu X, Zhang X, Hua W, et al. (2016). Inhibition of BRD4 suppresses tumor growth and enhances iodine uptake in thyroid cancer. Biochem. Biophys. Res. Commun. 469: 679-685. http://dx.doi.org/10.1016/j.bbrc.2015.12.008

Hong JH, Yi HS, Yi S, Kim HW, et al. (2016). Implications of oncocytic change in papillary thyroid cancer. Clin. Endocrinol. (Oxf.) 85: 797-804. http://dx.doi.org/10.1111/cen.13115

Huang Q, Xiao B, Ma X, Qu M, et al. (2016). MicroRNAs associated with the pathogenesis of multiple sclerosis. $J$. Neuroimmunol. 295-296: 148-161. http://dx.doi.org/10.1016/j.jneuroim.2016.04.014

Joyce DP, Kerin MJ and Dwyer RM (2016). Exosome-encapsulated microRNAs as circulating biomarkers for breast cancer. Int. J. Cancer 139: 1443-1448. http://dx.doi.org/10.1002/ijc.30179

Lu J, Getz G, Miska EA, Alvarez-Saavedra E, et al. (2005). MicroRNA expression profiles classify human cancers. Nature 435: 834-838. http://dx.doi.org/10.1038/nature03702

Matsuno A, Murakami M, Hoya K, Yamada SM, et al. (2013). Clinicopathological and molecular histochemical review of skull base metastasis from differentiated thyroid carcinoma. Acta Histochem. Cytochem. 46: 129-136. http://dx.doi. org/10.1267/ahc. 13019

Mutalib NS, Yusof AM, Mokhtar NM, Harun R, et al. (2016). MicroRNAs and lymph node metastasis in papillary thyroid cancers. Asian Pac. J. Cancer Prev. 17: 25-35. http://dx.doi.org/10.7314/APJCP.2016.17.1.25

Otsuka M, Kishikawa T, Yoshikawa T, Yamagami M, et al. (2016). MicroRNAs and liver disease. J. Hum. Genet. http:// dx.doi.org/10.1038/jhg.2016.53.

Pisarello MJ, Loarca L, Ivanics T, Morton L, et al. (2015). MicroRNAs in the cholangiopathies: pathogenesis, diagnosis, and treatment. J. Clin. Med. 4: 1688-1712. http://dx.doi.org/10.3390/jem4091688

Qi P, Wang L, Zhou B, Yao WJ, et al. (2015). Associations of miRNA polymorphisms and expression levels with breast cancer risk in the Chinese population. Genet. Mol. Res. 14: 6289-6296. http://dx.doi.org/10.4238/2015.June.11.2

Sun Q, Gu H, Zeng Y, Xia Y, et al. (2010). Hsa-mir-27a genetic variant contributes to gastric cancer susceptibility through affecting miR-27a and target gene expression. Cancer Sci. 101: 2241-2247. http://dx.doi.org/10.1111/j.13497006.2010.01667.x

Tang W, Yu F, Yao H, Cui X, et al. (2014). miR-27a regulates endothelial differentiation of breast cancer stem like cells. Oncogene 33: 2629-2638. http://dx.doi.org/10.1038/onc.2013.214

Thakur V and Bedogni B (2016). The membrane tethered matrix metalloproteinase MT1-MMP at the forefront of melanoma cell invasion and metastasis. Pharmacol. Res. 111: 17-22. http://dx.doi.org/10.1016/j.phrs.2016.05.019

Valderrabano P, Zota VE, McIver B, Coppola D, et al. (2015). Molecular assays in cytopathology for thyroid cancer. Cancer Contr. 22: 152-157.

Wang Q, Wang S, Wang H, Li P, et al. (2012). MicroRNAs: novel biomarkers for lung cancer diagnosis, prediction and treatment. Exp. Biol. Med. (Maywood) 237: 227-235. http://dx.doi.org/10.1258/ebm.2011.011192

Yin A, Wang C, Sun J, Gao J, et al. (2016). Overexpression of NDRG2 increases iodine uptake and inhibits thyroid carcinoma cell growth in situ and in vivo. Oncol. Res. 23: 43-51. http://dx.doi.org/10.3727/096504015X14452563486093

Genetics and Molecular Research 15 (4): gmr15049070 
Zhou S, Huang Q, Zheng S, Lin K, et al. (2016). miR-27a regulates the sensitivity of breast cancer cells to cisplatin treatment via BAK-SMAC/DIABLO-XIAP axis. Tumour Biol. 37: 6837-6845. http://dx.doi.org/10.1007/s13277015-4500-1

Zuo D, Chen L, Liu X, Wang X, et al. (2016). Combination of miR-125b and miR-27a enhances sensitivity and specificity of AFP-based diagnosis of hepatocellular carcinoma. Tumour Biol. 37: 6539-6549. http://dx.doi.org/10.1007/ $\underline{\text { s13277-015-4545-1 }}$

Genetics and Molecular Research 15 (4): gmr15049070 